\title{
Quality Seed: An Innovative Sorting Technique to Sustainable, Uniform and Effective Seedling Establishment in Nursery for System of Rice Intensification
}

\author{
Zubairu Usman Bashar ${ }^{1}$, Aimrun Wayayok ${ }^{1,2}$, Amin M. S. M. ${ }^{1,2} \&$ Razif M. Mahadi $^{1}$ \\ ${ }^{1}$ Department of Biological and Agricultural Engineering, Faculty of Engineering, Universiti Putra Malaysia, \\ Malaysia \\ ${ }^{2}$ Smart Farming Technology Research Centre, Faculty of Engineering, Universiti Putra Malaysia, 43400 \\ Serdang, Selangor DarulEhsan, Malaysia \\ Correspondence: Zubairu Usman Bashar, Department of Biological and Agricultural Engineering, Faculty of \\ Engineering, Universiti Putra Malaysia, Malaysia. E-mail: zubairug@yahoo.com
}

Received: April 4, 2014 Accepted: May 12, 2014 Online Published: June 15, 2014

doi:10.5539/jas.v6n7p185 URL: http://dx.doi.org/10.5539/jas.v6n7p185

\begin{abstract}
One of the major problems of adapting the System of Rice Intensification (SRI) techniques is knowledge shortfall on the technical skills for processing quality seeds to achieve uniform seedling establishment in the nursery and quick seedling recovery in the puddled field. Therefore, this study aimed to create suitably seed sorting technique leading to vigorous and quality seedlings to improve potentiality of SRI nursery and reduce seedlings transplanting shock. It involved sorting of MR2 19 rice seeds the most popular grown variety in Malaysia in $\mathrm{NaCl}$ solutions of 0 $\mathrm{g} / \mathrm{L}$ (water alone), $40 \mathrm{~g} / \mathrm{L}, 60 \mathrm{~g} / \mathrm{L}, 80 \mathrm{~g} / \mathrm{L}, 100 \mathrm{~g} / \mathrm{L}$ and $120 \mathrm{~g} / \mathrm{L}$, respectively. The experiment revealed that $100 \%$ germination after ten days was obtained from the sunken MR219 seeds collected in $80 \mathrm{~g} / \mathrm{L}$ of $\mathrm{NaCl}$ solution. These values reported a decrease in germination $(85 \%)$ with increasing $\mathrm{NaCl}$ concentration $(120 \mathrm{~g} / \mathrm{L})$, with least germination vigor of $42 \%$ in water alone $(0 \mathrm{~g} / \mathrm{L}) 3$ days. The percentage of sprouting proved to be high from the sunken seeds obtained in $80 \mathrm{~g} / \mathrm{L}$ with $100 \%$ sprouting success rate. A decrease in percentage $(70 \%)$ has been revealed with increasing $\mathrm{NaCl}$ concentration from the seeds obtained in $120 \mathrm{~g} / \mathrm{L}$ and also when it was reduced to 40 $\mathrm{g} / \mathrm{L}$ which reported $65 \%$ of the sprouting rate. Therefore, this technical information serves as benchmark to practicing farmers that high concentration in $\mathrm{NaCl}$ not only reduces the percentage of viable seeds but also increases seedling preparation cost as well as the entire production cost.
\end{abstract}

Keywords: germination vigor, MR219 rice, priming, salt solution, SRI

\section{Introduction}

Rice (Oryza Sativa in Asia or Oryza Glaberrima in Africa), classified as a monocotyledon plant because of its behavior of producing one leaf per growth development. Rice is considered as the staple food for a large part of Asia and Africa and also to some parts of Europe, America, and West Indies (FAO, 2012). Seeds from plants are usually covered with an outer shell to protect the endosperm, either for utilization as food or as a future source of continuity of the family - germinability of the plant. It is a mature rice grain that germinates under favorable environmental conditions and grows into a normal plant (Quality Rice Seed Production Manual). The quality of any seed can be clearly determined upon the physical characteristics exposed by its mother plant during growth stages, harvesting, processing, storage and planting. Likewise, temperature, nutrients and environmental factors also affect-the development and quality of the seed. Moreover, Misra et al. (1994) reported that good seeds are essential to good crop production and they are also today's treasure and hope for feeding future generations. Similarly, Mao et al. (1996) estimated that 1\% impurity in hybrid rice could bring down the yield potential by 100 $\mathrm{kg} / \mathrm{ha}$. Therefore, monitoring the genetic purity of rice is necessary to increase yield production (Mishra et al., 2003). Other studies have shown that genetic impurity, improper dryness, disease contamination, and pest infestation often do not manifest themselves until the seed is sown and has started to grow (Bradford, 2005).

Good quality rice seed is considered by cultural geographers as the type of seed that is fully matured, properly dried, and free from weed seeds and be able to regenerate a high percentage of viable seed or rather productive (Asaki et al., 2013; Bhabindra et al., 2012). This is the ability of the rice seed to grow and develop into an adult. 
Therefore, viable seeds are the seeds capable of germinating uniformly and rapidly thereby providing strong or vigorous seedlings (Adusumill \& Bhagya, 2010; Norman, 1993). Seed viability can be determined with respect to its moisture content, germination potential and vigor. Therefore, a viable seed results in seedlings which recover quickly from the transplanting shock, rapid root growth that enables the seedlings to draw nutrients quickly and effectively from the soil. Therefore, with all these advantages on quality seeds, it is now necessary to preserve and save the wastage during seedling and transplanting processes when compare to the existing practice of 15 to $25 \mathrm{~kg}$ on trays and 50 to $80 \mathrm{~kg}$ on wet and dry bed nurseries with up to $100 \mathrm{~kg}$ of seeds on direct seeding (Balasubramanian, 2009; Bhabindra et al., 2012; Dhananchezhiyan, Durairaj, \& Parveen, 2013)

\section{Materials and Methods}

\subsection{Sample and Sample Preparation}

The MR219 rice seeds for the study were obtained from Tanjong Karang rice growing area in Selangor, Malaysia. The sample seeds were manually cleaned so as to ensure that all foreign matters such as dirt, husk, immature or broken seeds, stones, weed-seeds and other inert materialshave been removed before storing, selling and reproducing (Coşkun et al., 2006; Garnayak et al., 2008; Solomon \& Zewdu, 2009). The main advantage of cleaning was to prevent the seeds from attack by insects, fungi and other pathogens that can endanger the seed thereby making it lose high potential of its genetic purity. The findings of Huynh et al. (2001) indicated that these pathogens caused lower germination of seed with transmission of disease from the seed to rice plant. Different methods of seed cleaning are now in use but the most common practical ones recommended by the Rice Knowledge Bank are winnowing (by wind blow), screening (by sieving with $\leq 1.4 \mathrm{~mm}$ sieve) and seed sorting (by salt and water solution) respectively. This technique has been encouraged in order to ensure sorting of good quality seeds. Pham et al. (2003) stated that the use of $15 \%$ brine solution for seed cleaning could improve the status of seed borne diseases infection and disease transmission.

\subsection{Seed Dormancy}

This is a period during which the time to germination may be high or low-depending on the variety of the rice seeds. In many varieties of rice, the dormancy period may presume immediately after the harvest. Hu et al. (2003) reported that in southern China, due to the long spell of rainy weather in early summer and autumn, seed dormancy causes heavy pre-harvest sprouting in the field for more than $6 \%$ of the rice acreage, which could be up to $20 \%$ for hybrid rice. It is therefore evidently important to note that knowledge on seed dormancy breaking plays a significant role in improving the genetic purity and seedlings establishment (Asaki et al., 2013; Michael et al., 2008). Kazuhiko et al. (2010) concluded that seed dormancy provides a strategy for flowering plants to survive adverse natural conditions. They also regarded it as an agronomic trait affecting grain yield, quality and processing performance.

\subsection{Selection and Sorting of Rice Seed}

Seed selection stands as the primary step of satisfying the SRI planting standards as well as establishing uniformly grown seedlings. Therefore, it is evident with the new SRI single seedling nursery tray to come up with best quality seeds selection method as every seed matters. Different methods were used to select better rice seeds for nursery purposes among these are seed sorting and seed soaking (water or salt solution) as reportedly used by Ella et al. (2011); Farooq et al. (2009). Therefore, this study involved the soaking of rice seeds in salty water solution thereby removing the floated as immature or an unfilled seeds with less endosperm and adapting/considering the sunken seeds as selected or best seeds. To obtain this salty level, an experiment was carried out in the Soil laboratory, Faculty of Engineering, UPM to determine the amount of salt needed to lift an egg in one liter of water where the egg was used as a reference for good seeds (Muhammad et al., 2006). This procedure involved the use of six sets of $300 \mathrm{ml}$ beakers and each was labeled as $\mathrm{S}_{1}, \mathrm{~S}_{2}, \mathrm{~S}_{3}, \mathrm{~S}_{4}, \mathrm{~S}_{5}$ and $\mathrm{S}_{6}$. Equal amount of distilled water $(250 \mathrm{ml})$ was poured into six beakers followed by insertion of an uncooked/fresh egg thereafter. It was noticed that the egg sunk to the bottom of all the beakers containing only the water, thus the latter indicated the viability of the egg and the accuracy of the experimental set up. A measured amount of salt of $5 \mathrm{~g}, 10 \mathrm{~g}, 15 \mathrm{~g}, 20 \mathrm{~g}$ and $25 \mathrm{~g}$ (using an electronic digital balance (Mitutoyo Digital Scale) with accuracy of $0.001 \mathrm{~g}$ were sequentially put in each of the five beakers, while the sixth beaker was left with no salt to serve as a control. Data on the gradual movement of egg to the surface was observed to whether the egg floats or not (Figure 1). A known amount of rice seeds (100) were placed in each of the six samples and the sorting process was followed thereby counting the number of floated and that of the sunken ones. Similarly, seeds that moved to the bottom were considered as good whereby the floating ones were discarded (Figure 2). The experiment was replicated three times and the mean value of each was obtained. 


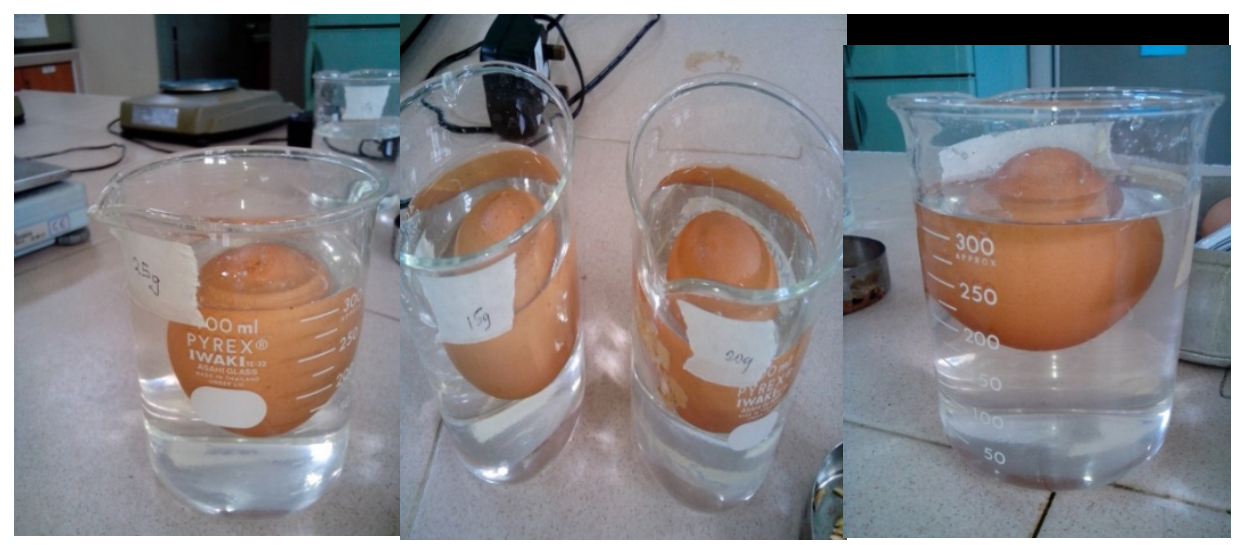

Figures 1. Egg floating at different $\mathrm{NaCl}$ concentration

\subsection{Seed Soaking}

The MR219 rice seeds were collected from the different sorting treatments and soaked after washing the salt content. The seeds were then placed in different containers and water was added thereafter for moisture absorption. This was kept for 24 hours in order to break the dormancy period (Figure 2) and initiate germination processes. Similar findings were reported (Ella et al., 2011; Farooq \& Basra, 2006; Guo et al., 2004; Haytham et al., 2010; Jeyabal \& Kuppuswamy, 1998; Maarten, Leónie, \& Henk, 2002; Michael et al., 2008; Naredo et al., 1998; Nouman et al., 2012; Wan et al., 2006).

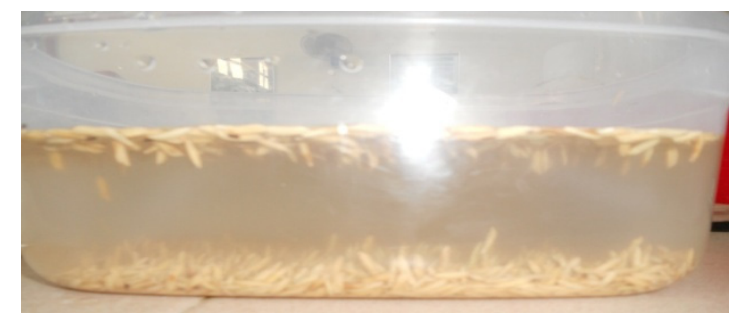

Figure 2. Showing sunken and floated seeds

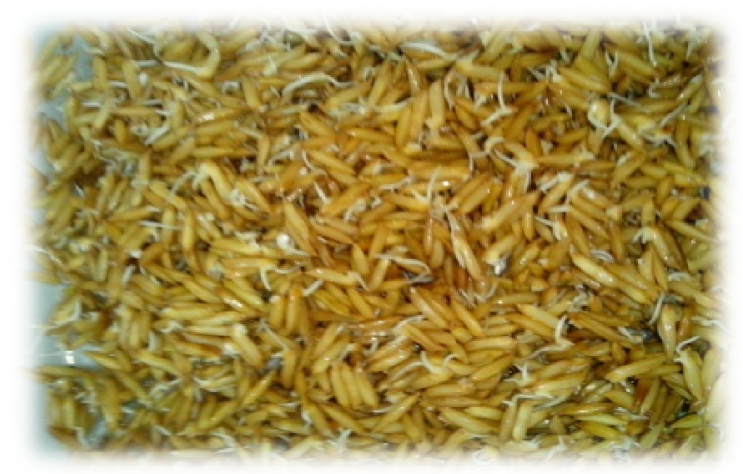

Figure 3. The sprouted rice seeds

\subsection{Seed Priming}

The theory of seed priming was first introduced by Heydecker in 1973 as reported by Sun et al. (2010) proved to be among the major prime movers of seedling establishment as well as escalated bumper harvest in rice production. Therefore, it was regarded as a technique of controlling the slow absorption and post - dehydration (Aboutalebian et al., 2012; Heydecker \& Coolbear, 1977; Nouman et al., 2012; Sun et al., 2010; Yari \& Sheidaie, 2011). This process involves soaking of MR219 rice seeds for 6 hours prior to sowing to ignite the germination process. These brilliant techniques have been validated by many scientific and research institutions on different crops. It increases 
the rate of germination and early seedling establishment especially in dry and semi-arid regions (Aboutalebian et al., 2012). It involved soaking, drying and exposing to a certain temperature until sprouting of MR219 rice seeds for 24hours, drained and kept under $40{ }^{\circ} \mathrm{C}$ for 6 hours in order to trigger germination process prior to sowing (Figure 3).

\subsection{Seed Germination}

Germination of seeds starts when the absorbed water reaches $25 \%$ of their weight, but it appears better by the time it goes to $40 \%$ of the seed weight, thus, a well soaked seed is dark, translucent and inflated and easily damaged by rubbing. Therefore, it is important to have the basic knowledge of germination factors such as root system, hypocotyls, plumule and cotylydons (Deno, 1993; Rajendran, 1991; Randall et al., 2004; Tuong \& Du, 2002) prior to the evaluation of any seedling establishment. This experiment was carried out in soil laboratory, UPM, with selected 100 MR219 rice seeds obtained from seed selection results at varying amount of $\mathrm{NaCl}$ of 40, 60, 80, 100 and $120 \mathrm{~g}$ per liter of distilled water. Moreover, the 100 sunken seeds obtained from each sample were due to addition of extra seeds in order to meet the required experimental plan. Likewise, equal number of seeds (100) was also placed in distilled water alone for sorting with addition of extra seeds to obtain the required 100 sunken seeds, thus, the selected seeds from all the treatments were set for germination test.

\section{Results and Discussions}

\subsection{Influence of Seed Selection at Varying $\mathrm{NaCl}$ Concentration}

In order to have effective and uniform seedling seedlings establishment in a nursery, proper care was taken the seed sorting. The results revealed that seeds sorted on $S_{1}, S_{2}$ and $S_{6}$ responded negatively to floating with seeds floating values of 8,13 and 2 when subjected to 40,60 and $0 \mathrm{~g} / \mathrm{L}$ of $\mathrm{NaCl}$ solution respectively. But an increase in floating ratio was observed when the concentration was increased to 80,100 and $120 \mathrm{~g} / \mathrm{L}$ of $\mathrm{NaCl}$ with floating values of 22, 27 and 34 respectively (Table 1). Therefore, salt concentration has indicated a significant influence on seed sorting thus the higher the concentration of salt the more number of floated seeds observed. The sunken seeds were considered to be the selected as the floating ones were considered as unfilled and/or immature seeds that are not capable of germinating uniformly when subjection to seedling nursery raising. These selected (sunken) seeds from the six beakers were then set for germination test to find which sample reveals the $100 \%$ germination success rate. The results indicated that seeds selected from $80 \mathrm{~g} / \mathrm{L}$ of salt concentration indicated $100 \%$ germination with a sorting condition of 22 floating and 78 sunken contrary to the increased in concentration of $120 \mathrm{~g} / \mathrm{L}$ with 34 (floated) and 66 (sunken) and revealing $85 \%$ of germination (Table 1). Other findings on seed selection and sorting of quality seed have been reported (Huynh et al., 2001; Islam et al., 2007; ISTA, 2012; Michael et al., 2008). Seed quality has been considered by paddy farmers as the primary instrument to the attainment of better seedling establishment, robust and uniformly stress-free seedlings as well as optimum yield when compare to the broadcasting practice where the establishment may not be uniform..

Table 1. Seed sorting technique tested for 100 seeds

\begin{tabular}{cccccc}
\hline \multirow{2}{*}{ Treatments } & \multirow{2}{*}{ Salt $(\mathrm{g} / \mathrm{L})$} & \multicolumn{2}{c}{ Egg floating status } & \multicolumn{2}{c}{ No. of seeds/100 } \\
\cline { 3 - 6 } & & Yes & No & Float & Sunken \\
\hline $\mathrm{S}_{1}$ & 40 & & $\sqrt{ }$ & 8 & 92 \\
$\mathrm{~S}_{2}$ & 60 & & $\sqrt{ }$ & 13 & 87 \\
$\mathrm{~S}_{3}$ & 80 & $\sqrt{ }$ & & 22 & 78 \\
$\mathrm{~S}_{4}$ & 100 & $\sqrt{ }$ & & 27 & 73 \\
$\mathrm{~S}_{5}$ & 120 & $\sqrt{ }$ & & 34 & 66 \\
$\mathrm{~S}_{6}$ & 0 & & $\sqrt{ }$ & 2 & 98 \\
\hline
\end{tabular}

\subsection{Effect of Seed Priming}

The MR219 has indicated significant variation in sprouting with the varying $\mathrm{NaCl}$ concentrations. Table 2 indicated that the percentage of sprouting was high from the sunken seeds obtained in $80 \mathrm{~g} / \mathrm{L}$ with $100 \%$ sprouting success rate. A decrease in percentage to $70 \%$ has been revealed from the seeds obtained in $120 \mathrm{~g} / \mathrm{L}$. Similarly, when the rate of concentration was reduced to $40 \mathrm{~g} / \mathrm{L}$ a decline was also noticed on the sprouting percentage to $65 \%$. Therefore, this variation was due to the high absorption of salt by the rice seeds. However, the findings of 
Farooq \& Basra (2006) on fine rice revealed that all the priming techniques responded well in improving the quality of seedling establishment, growth and yield except for the traditional soaking method in ordinary water, which the latter resulted in impaired germination, seedling establishment with a reduction on the yield. Furthermore, Lee et al. (1998) indicated that germination and emergence rates and time from planting to $50 \%$ of germination $\left(\mathrm{T}_{50}\right)$ of primed seed were $0.9-3.7$ days less than those of untreated rice seeds. Moreover, priming of rice seeds might be useful way to better seedling establishment under adverse soil condition (Lee et al., 1998). Therefore, these types of seeds (primed seeds) can be sown either manually or mechanically but should not be delayed for more than two days after priming. Consequently, Sun et al. (2010) on their findings revealed that seed priming could categorically improve the metabolism of rice seed, germination indices, drought tolerance and seedling quality with more pronouncing impact on indica than japonica rice varieties). This method was similarly reported by Yari and Sheidaie (2011) on rice seed and Liela et al. (2010) on wheat. Similar findings on various research works (M Farooq \& Basra, 2006; Jeyabal \& Kuppuswamy, 1998; Maarten et al., 2002; Nejad \& Farahmand, 2012; Tuong \& Du, 2002) also responded relatively as reported.

Table 2. Seed sprouting (\%)

\begin{tabular}{ccc}
\hline Treatments & Salt $(\mathrm{g} / \mathrm{L})$ & Sprouting $(\%)$ \\
\hline $\mathrm{S}_{1}$ & 40 & 60 \\
$\mathrm{~S}_{2}$ & 60 & 66 \\
$\mathrm{~S}_{3}$ & 80 & 100 \\
$\mathrm{~S}_{4}$ & 100 & 88 \\
$\mathrm{~S}_{5}$ & 120 & 75 \\
$\mathrm{~S}_{6}$ & 0 & 55 \\
\hline
\end{tabular}

\subsection{Influence of Seed Germination on Sorting Technique}

The result on seed germination indicated that at $10^{\text {th }}$ day after sowing, $90 \%$ of germinated seeds were recorded in $40 \mathrm{~g} / \mathrm{L}$ of NaCL - water solution, while the rate of germination increased from 90 to $100 \%$ when the concentration of $\mathrm{NaCl}$ was raised to $80 \mathrm{~g} / \mathrm{L}$ as reported in Figure 4 . This level $(80 \mathrm{~g} / \mathrm{L})$ also revealed germination vigor of $82 \%$ as against $69 \%$ when subjected to $120 \mathrm{~g} / \mathrm{L}$ of soluble $\mathrm{NaCl}$ shown in Table 2, respectively. But a surprising declination was observed when an increase in $\mathrm{NaCl}$ concentration was beyond $80 \mathrm{~g} / \mathrm{L}$ with a decreasing percentage of 85 from $120 \mathrm{~g} / \mathrm{L}$ as against $100 \%$ in $80 \mathrm{~g} / \mathrm{L}$ (Table 3). Therefore, this decrease was attributed due to the presence of high salt absorbed by the seed as reported by Turhan et al. (2011) on Spinach cultivars, Akbarimoghaddam et al. (2011) on wheat, Bojović et al. (2010) on Brassicaceae and Solanaceae seeds and found that seeds of all species germinate only at low $\mathrm{NaCl}$ concentration. Other research findings on the effect of salt to seedling growth were reported (Cordazzo, 1999; Kaymakanova, 2009; Kiani et al., 2011; Mohammad et al., 2011; Mostafavi, 2012; Schneider and Bouali, 2010; Sivasankaramoorthy et al., 2010) who studied on different seeds and drawn similar conclusion on the decrease in germination as $\mathrm{NaCl}$ increased. This can therefore be concluded that increase in salt concentration is not an indicator to quality seed selection rather it only makes farmers to employ more seeds with low potential germination output.

Table 3. Germination rate with respect to seed sorting

\begin{tabular}{ccccccccccc}
\hline \multirow{2}{*}{ NaCl Solution $(\mathrm{g} / \mathrm{L})$} & \multicolumn{10}{c}{ Germination per day $(\%)$} \\
\cline { 2 - 11 } & 1 & 2 & 3 & 4 & 5 & 6 & 7 & 8 & 9 & 10 \\
\hline 40 & 0 & 0 & 68 & 72 & 77 & 83 & 90 & 90 & 90 & 90 \\
60 & 0 & 0 & 78 & 77 & 80 & 86 & 93 & 93 & 93 & 93 \\
80 & 0 & 0 & 82 & 88 & 92 & 98 & 100 & 100 & 100 & 100 \\
100 & 0 & 0 & 74 & 78 & 82 & 86 & 89 & 89 & 89 & 89 \\
120 & 0 & 0 & 69 & 72 & 76 & 82 & 84 & 85 & 85 & 85 \\
0 & 0 & 0 & 42 & 56 & 61 & 64 & 67 & 67 & 67 & 67 \\
\hline
\end{tabular}




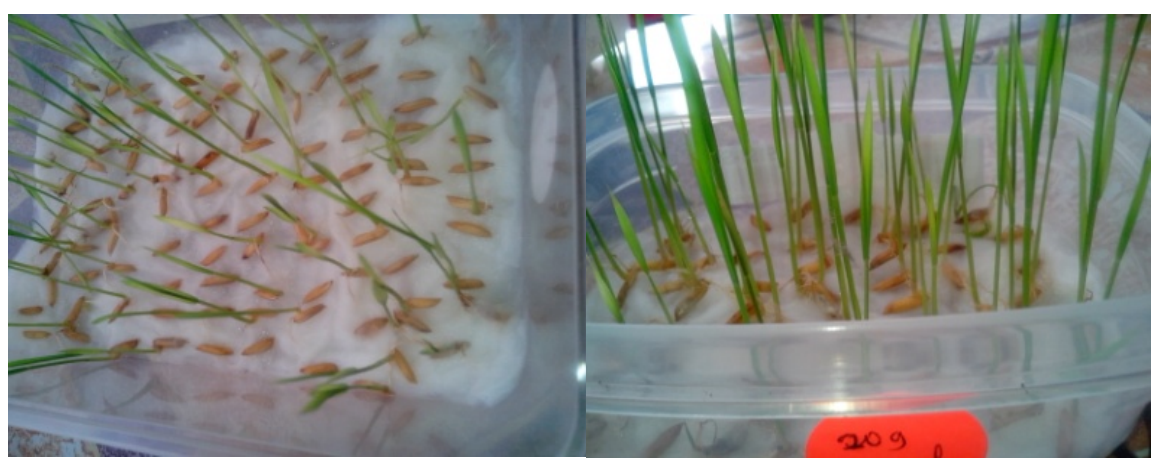

Figure 4. Photos of seed germination after sorting using $\mathrm{NaCl}$ concentration of $80 \mathrm{~g} / \mathrm{L}$

\section{Conclusion}

Seed quality stands as the primary source to proper nursery and quick seedling establishment in the puddled field. Therefore, these results indicated that high concentration of salt during seed sorting does not only reduce the percentage of viable seeds required per planting area but also increases the production cost due wastage of viable seeds as well as encourage poor seedling establishment with resulted to high intake of $\mathrm{NaCl}$ and lower the yield.

\section{Acknowledgement}

The authors express their sincere appreciation and gratitude to the Uninersiti Putra Malaysia for the fund released through the Research University Grant Scheme (RUGS) on project number: 05-02-12-2199RU (Vot 9376900) for the successful taking and completion of the study.

\section{References}

Aboutalebian, M. A., Ekbatani, G. Z., \& Sepehri, A. (2012). Effects of on-farm seed priming with zinc sulfate and urea solutions on emergence properties, yield and yield components of three rainfed wheat cultivars. Annals of Biological Research, 3(10), 4790-4796.

Adusumill, i R., \& Bhagya Laxmi, S. (2010). Potential of the system of rice intensification for systemic improvement in rice production and water use: the case of Andhra Pradesh, India. Paddy and Water Environment, 9(1), 89-97. http://dx.doi.org/10.1007/s10333-010-0230-6

Akbarimoghaddam, H., Galavi, M., Ghanbari, A., \& Panjehkeh, N. (2011). Salinity Effects on Seed Germination. Trakia Journal of Sciences, 9(1), 43-50.

Asaki, K. S., Azama, Y. K., Hae, Y. C., \& Ato, T. S. (2013). Confirmation of Novel Quantitative Trait Loci for Seed Dormancy at Different Ripening Stages in Rice. Rice Science, 20(1).

Balasubramanian, V. (2009). Rice Nursery and Early Crop Management. Powerpoint. IRRI: Rice production course.

Bhabindra, N., Pokhrel, D. R., \& Jha, S. (2012). Seed attributes, germination responses and seedling growth of silk cotton tree Bombax ceiba L . Nepalese Journal of Biosciences, 2(April 2009), 109-112.

Bojović, B., Đelić, G., Topuzović, M., \& Stanković, M. (2010). Effects of $\mathrm{NaCl}$ on seed germination in some species from families Brassicaceae and Solanaceae. Kragujevac J. Sci., 32, 83-87.

Bradford, Kent, J. (2005). Methods to Maintain Genetic Purity of Seed Stocks.

Cordazzo, C. V. (1999). Effects of salinity on seed germination, seedling growth and survival of spart/NAC/L/ATA BRONG. Acta Bot. Bras., 13(3), 317-322.

Coşkun, M. B., Yalçın, İ., \& Özarslan, C. (2006). Physical properties of sweet corn seed (Zea mays saccharata Sturt.). Journal of Food Engineering, 74(4), 523-528. http://dx.doi.org/10.1016/j.jfoodeng.2005.03.039

Dhananchezhiyan, P., Durairaj, C. D., \& Parveen, S. (2013). Development of nursery raising technique for "system of rice intensification" machine transplanting. African J. of Agric. Res., 8(29), 3873-3882. http://dx.doi.org/10.5897/AJAR2013.7465

Ella, E. S., Dionisio-Sese, M. L., \& Ismail, A. M. (2011). Seed pre-treatment in rice reduces damage, enhances carbohydrate mobilization and improves emergence and seedling establishment under flooded conditions. AoB Plants, 2011, plr007. http://dx.doi.org/10.1093/aobpla/plr007 
FAO. (2012). The State of Food Insecurity in the World 2012 (p. 65).

Farooq, M., \& Basra, S. (2006). Seed priming enhances emergence, yield, and quality of direct-seeded rice. Crop Management \& Phisiology. Retrieved from http://agris.fao.org/agris-search/search/display.do?f=2007/QR /QR0705.xml;qr2007000037

Farooq, M., Basra, S. M. A., Tabassum, R., \& Afzal, I. (2006). Enhancing the Performance of Direct Seeded Fine Rice by Seed Priming. Plant Prod. Sci., 9(April), 446-456.

Farooq, M., Kabayashi, N., Wahid, A., \& Bassa, O. M. (2009). Strategies for producing more rice with less water. Advance in Agronomy, 101, 351-388.

Garnayak, D. K., Pradhan, R. C., Naik, S. N., \& Bhatnagar, N. (2008). Moisture-dependent physical properties of jatropha seed (Jatropha curcas L.). Industrial Crops and Products, 27(1), 123-129. http://dx.doi.org/10.1016/j.indcrop.2007.09.001

Guo, L., Zhu, L., Xu, Y., Zeng, D., Wu, P., \& Qian, Q. (2004). QTL analysis of seed dormancy in rice (Oryza sativa L.). Euphytica, 140(3), 155-162. http://dx.doi.org/10.1007/s10681-004-2293-1

Haytham, M. E., Hassaanein, M. K., Zahoor, A., \& Kotamy, T. M. El. (2010). Rice Straw-Seedbed for Producing Rice Seedling Mat. Internationa Journal of Sustainable Agriculture, 2(2), 26-33.

Heydecker, W., \& Coolbear, P. (1977). Seed treatment for improved performance of survey and attempted prognosis. Seed Sci. \& Technol., 5, 353-425.

Hu, W. ., Ma., H. S., Fan., L. J., \& Ruan, S. I. L. (2003). Characteristics of pre-harvest sprouting in sterile lines in hybrid rice seeds production. Acta Agronomica Sinica, 3, 441-446.

Huynh, V. N., Pham, V. D., \& Mathur, S. B. (2001). Effect of cleaning on seed health and seed germination of rice. OMonRice, 9, 138-139.

Islam, M. A., Khalequzzaman, K. M., Ali, M. A., Officer, S. S., Officer, S., Division, P. P., \& Agricultural, R. (2007). Study of seed health, germination and seedling vigor of farmers produced rice seeds. Int. J. Sustain. Crop Prod., 2(November), 34-39.

ISTA. (2012). International Rules for Seed Testing Edition 2012 (p. 248). The International Seed Testing Association (ISTA), Zurichstr.50, CH-8303 Bassersdorf, Switzerland.

Jeyabal, A., \& Kuppuswamy, G. (1998). Effect of Seed Soaking on Seedling Vigour, Growth and Yield of Rice. Journal of Agronomy and Crop Science, 180(3), 181-190. http://dx.doi.org/10.1111/j.1439-037X.1998.tb003 88. $\mathrm{x}$

Kaymakanova, M. (2009). Effect of salinity on germination and physiology in bean ( PHASEOLUS VULGARIS L .). In IX Anniversary Scientific Conference (pp. 326-329).

Kazuhiko, S., Takeuchib, Y., Ebanaa, K., Miyaoa, A., Hirochikaa, H., Haraa, N., ... Yanoa, M. (2010). Molecular cloning of Sdr4, a regulator involved in seed dormancy and domestication of rice. In K. Maarten (Ed.), National Academy of Sciences of the United State of America. National Academy of Sciences of the United State of America. Retrieved from http://www.pnas.org/content/107/13/5792.long

Kiani, A., Mohammad, A., Nasr, H., Hojjati, M., \& Bayat, D. (2011). Salt effects on seed germination and seedling emergence of two Acacia species. African Journal of Plant Sciences, 5(January), 52-56.

Lee, S. S., Kim, J. P., Hong, S. B., Yun, S. H., \& Park, E. (1998). Priming effect of rice seeds on seedling establishment under adverse soil condition. Korean Journal of Crop Science, 43, 194-198.

Liela, Y., Majid, A., \& Fardin, K. (2010). Effect of seed priming duration and temperatureon seed germination behavior of bread wheat (Triticum). Journal of Agricultural and Biological Science, 5(1), 1-6.

Maarten, K., Leónie, B., \& Henk, H. (2002). Seed dormancy and germination. Plant Biology, 5, 33-36.

Mao, C. X., Virmani, S., \& Kumar, K. (1996). Tecnological innovations to lower the costs of hybrid rice seed production. In S. Virmani (Ed.), Advances in hybrid rice technology. Proceedings of Third International Symposium on Hybrid Rice, Directorate of Rice Research, Hyderabad, India.

Michael, J. H., William, E. F., Phillipe, G., \& Dominique, G. (2008). Post-genomics dissection of seed dormancy and germination. Trends in Plant Science, 13(1), 7-13. http://dx.doi.org/10.1016/j.tplants.2007.11.002

Mishra, B., Viraktamath, B., Ilyas Ahmed, M., Ramesha, M., \& Vijayakumar, C. (2003). Hybrid rice research and development in India. In S. Virmani, C. Mao, \& B. Hardy (Eds.), Hybrid rice for food security, poverty 
alleviation, and environmental protection. (pp. 265-283). Proceedings of the 4th International Symposium on Hybrid Rice, 14-17 May 2002, Hanoi, Vietnam. Los Baños (Philippines), International Rice Research Institute.

Misra, J. K., Mew, T. W., \& Merca, S. D. (1994). Rice seed health and quarantine. In T. W. Mew \& J. K. Misra (Eds.), A Manual of Rice Seed Health Testing (p. 122). International Rice Researcg Institute, Los Banos, Laguna, Philippines Box 933, 1099 Metro Minila, Philippines.

Mohammad, H. B. K., Mehrnaz, S. O. R., Mohsen, S. M., \& Amir, P. L. (2011). Effect of salt (NaCl) stress on germination and early seedling growth of Spinach ( Spinacia oleracea L.). Annals of Biological Research, 2(4), 490-497.

Mostafavi, K. (2012). Effect of Salt Stress on Germination and Early Seedling Growth Stage of Sugar Beet. American-Eurasian Journal of Sustainable Agriculture, 6(2), 120-125.

Naredo, M. E. B., Amita, B. J., Lu, B. R., Guzman., F. de, \& Jackson, M. T. (1998). Responses to seed dormancybreaking treatments in rice species (Oriza L.). Seed Sci. \& Technol., 26, 675-689.

Nejad, H. A., \& Farahmand, S. (2012). Evaluating the potential of seed priming techniques in improving germination and early seedling growth of Aeluropus Macrostachys under salinity stress condition. Annals of Biological Research, 3(11), 5099-5105.

Norman C. Deno. (1993). Seed germination theory and practice (second ed., p. 248). Pennsylvania state unineristy, 139 Lenor Drive, State College PA 16801, USA.

Nouman, W., Siddiqui, M. T., Maqsood, S., Basra, A., \& Afzal, I. (2012). Enhancement of emergence potential and stand establishment of Moringa oleifera Lam . by seed priming. Turk J Agric For, 36, $227-235$. http://dx.doi.org/10.3906/tar-1103-39

Pham, V., Huynh, V., \& Nguyen, D. (2003). Application of seed cleaning in management of seed borne diseases of rice. OMonRice, 9, 103-109.

Rajendran, R. (1991). Nursery manuring and its effect on seedling growth and yield of rice. Andras Agric, Journal, $78,73-75$.

Randall, R. J., Rajendran, R., Balasubramanian, V., Ravi, V., Valliappan, K., \& Jayaraj, T. (2004). Nursery technology for early production of robust rice seedlings to transplant under integrated crop management. IRRN.

Schneider, L., \& Bouali, A. (2010). Role of salt stress on seed germination and growth of Jojoba plant (SIMMONDSIA CHINENSIS). IUFS Journal of Biology, 69(1), 33-39.

Sivasankaramoorthy, S., Balasubramanian, T., Amuthavalli, P., \& Sivaraman, P. (2010). The effect of NaCl salinity on seed germination of Excoecaria agallocha L . Current Botany, 1(1), 10-12.

Solomon, W. K., \& Zewdu, a. D. (2009). Moisture-dependent physical properties of niger (Guizotia abyssinica Cass.) seed. Industrial Crops and Products, 29(1), 165-170. http://dx.doi.org/10.1016/j.indcrop.2008.04.018

Sun, Y.-Y., Sun, Y.-J., Wang, M.-T., Li, X.-Y., Guo, X., Hu, R., \& Ma, J. (2010). Effects of Seed Priming on Germination and Seedling Growth Under Water Stress in Rice. Acta Agronomica Sinica, 36(11), 1931-1940. http://dx.doi.org/10.1016/S1875-2780(09)60085-7

Tuong, T. P., \& Du, L. V. (2002). Enhancing the performance of dry-seeded rice: Effects of seed priming, seedling rate and time of seeding. In S. Pandey, M. Mortimer, L. Wade, T. P. Tuong, K. Lopez, \& B. Hardy (Eds.), Direct seeding: Research strategies and opportunities (pp. 241-256). International Research Institute, Manila, Philippines.

Turhan, A., Kuşçu, H., \& Şeniz, V. (2011). Effects of Different Salt Concentrations ( NaCl ) on Germination of Some Spinach Cultivars Farklı Tuz $(\mathrm{NaCl})$ Konsantrasyonlarının Bazı Ispanak Çeşitlerinde. Journal of Agricu;ltural Faculty of Uludag University, 77, 65-77.

Wan, J. M., Jiang, L., Tang, J. Y., Wang, C. M., Hou, M. Y., Jing, W., \& Zhang, L. X. (2006). Genetic dissection of the seed dormancy trait in cultivated rice (Oryza sativa L.). Plant Science, 170(4), 786-792. http://dx.doi.org/10.1016/j.plantsci.2005.11.011

Yari, L., \& Sheidaie, S. (2011). Effect of seed priming on seed germination's behavior of rice (Oryza sativa L.). Journal of Agricultural and Biological Science, 1(June), 45-51. 


\section{Copyrights}

Copyright for this article is retained by the author(s), with first publication rights granted to the journal.

This is an open-access article distributed under the terms and conditions of the Creative Commons Attribution license (http://creativecommons.org/licenses/by/3.0/). 